This paper reports the full-scale experimental measurements of temperature distribution over the surfaces of bridges' steel-concrete beams under the influence of positive and negative ambient temperatures. It has been established that the temperature is distributed unevenly along the vertical direction of a bridge's steel-concrete beam.

It was found that the metal beam accepted higher temperature values. The maximum registered temperature difference between a metal beam and a reinforced concrete slab at positive ambient temperatures was $+9.0^{\circ} \mathrm{C}$, and the minimum temperature difference was $-2.1{ }^{\circ} \mathrm{C}$.

The mathematical models for calculating a temperature field and a thermally strained state of bridges' steel-concrete beams under the influence of variable climatic temperature changes in the environment have been improved, taking into consideration the uneven temperature distribution across a bridge's reinforced concrete beam. The possibility has been established to consider a one-dimensional problem or to apply the three-dimensional estimated problem schemes as the estimation schemes for determining the thermo-elastic state of reinforced concrete bridges.

The temperature field and the stressed state of bridges' reinforced concrete beams were determined. It was found that the maximum stresses arise at the place where a metal beam meets a reinforced concrete slab. These stresses amount to 73.4 MPa at positive ambient temperatures, and 69.3 MPa at negative ambient temperatures.

The amount of stresses is up to $35 \%$ of the permissible stress values. The overall stressed-strained state of a bridge's reinforced concrete beams should be assessed at the joint action of temperature-induced climatic influences and loads from moving vehicles

Keywords: road bridge, reinforced concrete beam, temperature fields, temperature stresses, ambient temperature

\section{A COMPREHENSIVE PROCEDURE FOR ESTIMATING THE STRESSED- STRAINED STATE OF A REINFORCED CONCRETE BRIDGE UNDER THE ACTION OF VARIABLE ENVIRONMENTAL TEMPERATURES}

\author{
Vitalii Kovalchuk \\ Doctor of Technical Sciences, Associate Professor \\ Department of Bridges and Tunnels* \\ E-mail: kovalchuk.diit@gmail.com \\ Artur Onyshchenko \\ Doctor of Technical Sciences, Associate Professor \\ Department of Bridges and Tunnels* \\ O lexander Fedorenko \\ Acting General Director, Deputy General Director for Production Development \\ Kyivavtodor Municipal Corporation \\ Petra Bolbochana str., 6, Kyiv, Ukraine, 01014 \\ Mykola Habrel \\ Doctor of Technical Sciences, Professor \\ Department of Architectural Design** \\ E-mail: gabrelmikola@gmail.com \\ Bogdan Parneta \\ $\mathrm{PhD}$, Associate Professor \\ Department of Building Production** \\ O leh Voznyak \\ $\mathrm{PhD}$, Associate Professor \\ Department of Transport Technologies \\ Lviv Branch of the Dnipro National University of Railway Transport named after \\ academician V. Lazaryan \\ I. Blazhkevycha str., 12a, Lviv, Ukraine, 79052 \\ Ruslan Markul \\ $\mathrm{PhD}$, Associate Professor \\ Department of Transport Infrastructure \\ Dnipro National University of Railway Transport named after Academician V. Lazaryan \\ Lazaryan str., 2, Dnipro, Ukraine, 49010 \\ Mariana Parneta \\ Department of Architectural Design** \\ Roman Rybak \\ Department of Building Production** \\ *National Transport University \\ M. Omelianovycha-Pavlenka str., 1, Kyiv, Ukraine, 01010 \\ ** Lviv Polytechnic National University \\ S. Bandery str., 12, Lviv, Ukraine, 79013
}

1. Introduction

Reinforced concrete bridges are an important component of the transport infrastructure of motorways. Such bridges are used to cover large spans, which makes them an integral part of the transport infrastructure [1]. Given significant temperature changes in the environment, the beams of reinforced concrete bridges are exposed to damage that 
leads to a decrease in their bearing capacity. The results from large-scale inspections of reinforced concrete bridges along railway tracks and motor roads, reported in works [2,3], showed that the greatest amount of damage to the beams occurs in the area of a rigid connection between a metal beam and a reinforced concrete slab. There are damages in the form of propagating longitudinal and transverse cracks, concrete chipping, disrupted integrity of the connection, etc.

The issue of determining the impact of climatic temperature changes on the stressed-strained state of reinforced concrete bridges includes a comprehensive component. First, to determine the actual stressed-strained state of reinforced concrete beams, it is necessary to register the maximum and minimum temperature values at the surfaces of a bridge's beams, then determine the distribution of a temperature field over a complex geometric surface of the beam. And only afterward it is possible to assess the stressed-strained state of bridges' steel-concrete beams caused by temperature-induced climatic influences.

It should be noted that there are no clear-cut recommendations for assessing the impact of climatic temperature changes in the environment on the stressed-strained state of bridge structures $[4,5]$. However, work [6] states that in the operational conditions of bridges temperature values constantly fluctuate, which causes a change in the stresses state of bridge structures, and, accordingly, a decrease in their bearing capacity.

Therefore, improving the theory and practice of calculating the temperature stresses and deformations in bridges' reinforced concrete beams could make it possible to use such materials for structural solutions that would meet the actual conditions of their subsequent operation. The is why it is a relevant task to devise a comprehensive procedure for determining the stressed-strained state of reinforced concrete bridges under the influence of variable climatic temperature changes in the environment. Such research would provide, in the future, for the reliable assessment, together with the effect of static and dynamic loads from vehicles, of the bearing capacity of reinforced concrete bridges.

\section{Literature review and problem statement}

Designing bridge structures implies their constant exposure to temperature-induced climatic influences.

In [7], the authors proposed a Calgary model to account for the distribution of temperature along the vertical direction of the pre-strained reinforced concrete beams of a bridge. A given model takes into consideration the uneven temperature distribution depending on the shape of the walls and shelves of the beam. However, the model fails to consider various structural materials; only a single material, concrete, is adopted, which does not relate to reinforced concrete bridges.

Works $[8,9]$ established that fluctuations in the daily and seasonal changes in ambient temperature affect the stressed state of pre-strained concrete bridges. Such changes cause stress and deformation of the bridge beams. Reducing the temperature gradient by $10{ }^{\circ} \mathrm{C}$ decreases the initial level of stresses by $3 \%$ to $7 \%$, deformations - by $26 \%$ to $40 \%$. However, the cited works did not assess the thermally strained state of the reinforced concrete beams of a bridge.

Papers [10,11] suggested a simplified scheme of temperature distribution in the vertical direction of reinforced concrete beams of bridges. The authors also gave the characteristic values of the maximum and minimum temperatures that occur at the surfaces of beams due to the action of uniform heat flows. However, the cited papers did not resolve the issue related to the thermally strained state of reinforced concrete beams while addressing temperature only.

According to regulations [12], climatic temperature influences must be taken into consideration when assessing the stressed state of bridge structures while calculating the second group of boundary states. The temperature of a metal beam should be accepted at the level exceeding the ambient temperature by $10{ }^{\circ} \mathrm{C}$.

Work [13] reports the results of a five-year-long study into the so-called "effective temperature" of a bridge, which affects the longitudinal movement of the bridge flooring. The bridge deformations and temperature were measured continuously during the day and at different periods of the year. As a result, it was established that the temperature deformations of the bridge flooring are not linear but follow a complex pattern instead, which depends on fluctuations in ambient temperature. Therefore, when designing bridges, it is recommended that a nonlinear temperature distribution should be set in the transverse and longitudinal directions of a bridge's beams. However, the cited work did not assess the level of temperature stresses in bridges.

When studying a temperature gradient in the box-shaped beams of a bridge [14], it was established that the temperature between the upper and lower part of the box-shaped beam is not evenly distributed. The temperature difference could reach values exceeding $40{ }^{\circ} \mathrm{C}$. The maximum temperature difference, as well as the maximum temperature, occurs around 8 p.m. on a sunny day. However, the cited study did not assess the level of temperature stresses in the box-shaped beams of the bridge.

Works $[15,16]$ analyzed the effect of temperature on the dynamic behavior of bridges, as well as built a model for establishing the degree of damage to bridge structures due to temperature influences. It was found that the horizontal movements of a bridge increase with an increase in ambient temperature. However, there were no studies of temperature deformations and stresses due to climatic temperature changes reported in [15].

The European Committee on Concrete set up a special group to study thermal effects in concrete bridges - "Thermal Effects" [17].

Paper [18] states that the thermally strained state of a reinforced concrete bridge is determined by the geometry of a bridge's span structures and its orientation in space relative to the sides of the horizon. It was established that fluctuations in ambient temperature lead to the transverse and longitudinal movements of reinforced concrete beams of the bridge, which, once they exceed the permissible values, could lead to defects in a reinforced concrete slab and a metal beam.

Paper [19] reports the results of the assessment of the temperature field and the thermally strained state of metal corrugated structures of small bridges. It was established that the effect of ambient temperature on the stressed state of metal structures is significant. Stresses could reach up to $40 \%$ of permissible values. It is noted that the level of temperature stresses is considerable and, when combined with stresses from vehicles, could lead to premature decommissioning of metal structures.

Work [20] assessed the stressed-strained state of a reinforced concrete pipe, strengthened by a metal corrugated 
structure, depending on the effects of climatic temperature influences. It was established that the maximum temperature stresses arise in the contact zone of the metal structure with a reinforced concrete pipe. It is noted that such stresses must be taken into consideration when designing similar structures.

Consequently, temperature stresses in bridge structures depend on many factors such as the location of a bridge relative to the sides of the horizon, the massiveness of the structure, construction conditions, and the characteristics of the climatic conditions of the area. Therefore, it is necessary to individually work out measures to reduce the risk of critical temperature stresses and deformations for each bridge.

Our analysis of the scientific literature reveals that none of the cited works has resolved the issue related to determining the thermally strained state of reinforced concrete bridge beams, which include different structural materials. This is relevant for reinforced concrete bridges whose beams are composed of a reinforced concrete slab rigidly connected to a metal beam. In addition, the cited papers failed to report a procedure for assessing the temperature field of reinforced concrete beams at the boundary between two structural materials, metal and reinforced concrete, which are different in their physical and mechanical parameters. This is important since the level of a temperature field would affect the level of temperature stresses and deformations in reinforced concrete bridges, which could lead to cracks and corrosion of bridge beams.

A comprehensive procedure for assessing the stressedstrained state of bridges exposed to the action of variable climatic influences would make it possible to establish the level of temperature stresses and deformations, as well as their impact, on the general thermally strained state of reinforced concrete bridges, which must be taken into consideration when designing them.

\section{The aim and objectives of the study}

The purpose of this work is to devise a comprehensive procedure for determining temperature stresses and deformations in the reinforced concrete beams of bridges under the influence of variable climatic temperature changes in the environment.

To accomplish the aim, the following tasks have been set:

- to perform experimental measurements of temperature distribution along the vertical direction of a bridge's reinforced concrete beam under the influence of variable ambient temperatures;

- to improve the analytical mathematical model for assessing the temperature field and temperature stresses and deformations of a bridge's reinforced concrete beams under the influence of climatic ambient temperatures;

- to determine the temperature stresses and deformations of reinforced concrete beams in bridges by using a numerical method.

\section{Materials and methods to study the thermally strained state of reinforced concrete bridges}

To determine the boundary conditions for a thermal conductivity problem, it is necessary to acquire data from experimental studies of temperature distribution over surfaces.
Our experimental measurements of temperature distribution at the surfaces of a bridge's reinforced concrete beam were carried out using the pyrometer HT-822 (Taiwan). The study object was a bridge located at $\mathrm{km} \mathrm{9+442} \mathrm{of} \mathrm{the} \mathrm{T-} 09-10$ motor road Burshtyn-Kalush, Ivano-Frankivsk oblast (Ukraine). The facade of the bridge is shown in Fig. 1.

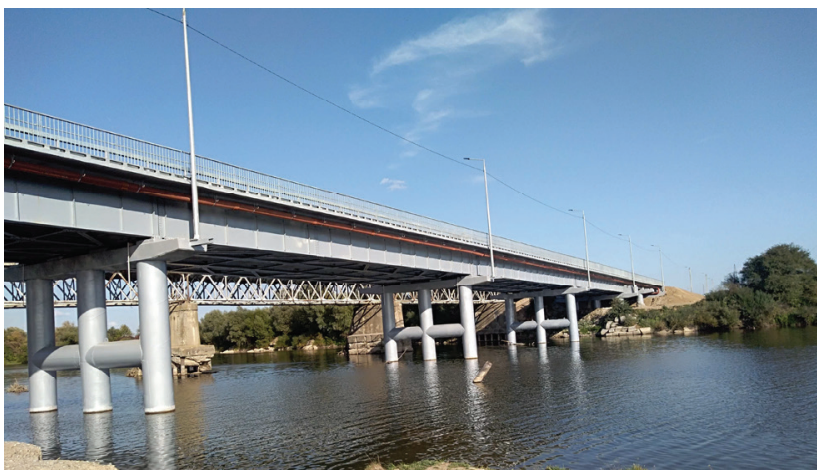

Fig. 1. Facade of the investigated bridge (Ukraine)

The bridge is located along a plan-straight section of the motor road. The design length of the bridge is $240.95 \mathrm{~m}$. Four runs of the bridge with a length of $33 \mathrm{~m}$ are made of reinforced concrete, the rest of the runs are reinforced concrete. The cross-section of the bridge hosts four steel I-beams with a length of $33 \mathrm{~m}$, a full height of $1.832 \mathrm{~m}$, and an edge height of $1.8 \mathrm{~m}$, connected by a monolithic reinforced concrete slab of the carriageway with a thickness of $0.2 \mathrm{~m}$ (in the slab run), as well as transverse and wind steel ties.

The process of measuring the temperature on the beams of the run structures of the bridge and the scheme of points for measuring temperature are shown in Fig. 2.

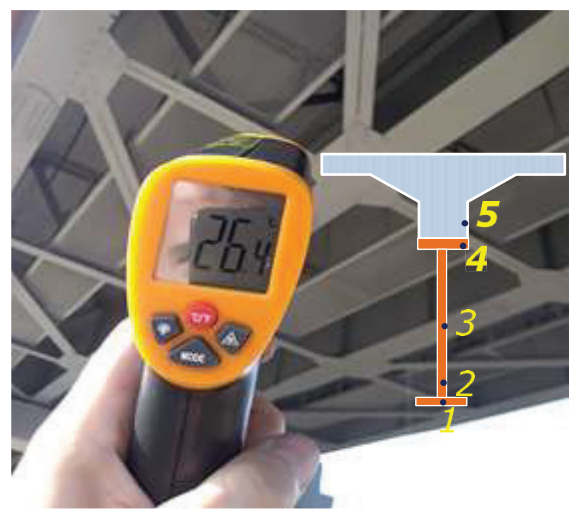

Fig. 2. Temperature measurement at the surface of the reinforced concrete beam of the bridge

We measured temperature distribution in the vertical direction of the reinforced concrete beam of the bridge at five points. The first point of measurement is located on the lower shelf of the metal beam, the second and third points are on the wall of the metal beam, the fourth point is the upper shelf of the metal beam, and the fifth point is the reinforced concrete slab.

Experimental temperature distribution data in the vertical direction of the reinforced concrete beam were treated using the IRSoft software.

The finite-element Femap 9.3 NX Nastran software was employed in the numerical modeling of the temperature field distribution and during the estimation of temperature stresses and deformations in the bridge's reinforced concrete beam. 


\section{Results of studying the thermally strained state of the bridge's reinforced concrete beams}

5.1. Results from the experimental measurements of temperature distribution at the surfaces of a reinforced concrete beam of the bridge

The results of temperature distribution in the vertical direction of the reinforced concrete beam of the bridge are given in Table 1.

Table 1

Results from the experimental measurements of temperature distribution in the vertical direction of the reinforced concrete beam of the bridge

\begin{tabular}{|c|c|c|c|c|c|c|c|}
\hline \multirow{2}{*}{$\begin{array}{c}\text { Measure- } \\
\text { ment date }\end{array}$} & $\begin{array}{c}\text { 24- } \\
\text { hour } \\
\text { period }\end{array}$ & $\begin{array}{c}\text { Air tempera- } \\
\text { ture, }\end{array}{ }^{\circ} \mathrm{C}$ & \multicolumn{5}{|c|}{ Temperature measurement point } \\
\cline { 2 - 8 } & $8: 00$ & $T_{a}$ & $T_{1}$ & $T_{2}$ & $T_{3}$ & $T_{4}$ & $T_{5}$ \\
\hline \multirow{5}{*}{25.09 .2020} & 9.2 & 9.2 & 9.6 & 9.5 & 10.5 \\
\cline { 2 - 8 } & $9: 00$ & 11 & 11.4 & 11.2 & 12.7 & 12.4 & 11.7 \\
\cline { 2 - 8 } & $10: 00$ & 14 & 15.4 & 15.4 & 15.7 & 14.2 & 14.0 \\
\cline { 2 - 8 } & $11: 00$ & 18 & 21.4 & 20.7 & 21.1 & 20.5 & 17.2 \\
\cline { 2 - 8 } & $12: 00$ & 20 & 24.4 & 25.4 & 26.4 & 25.1 & 23.4 \\
\cline { 2 - 8 } & $13: 00$ & 24 & 27.3 & 27.7 & 28.9 & 26.1 & 25.4 \\
\cline { 2 - 8 } & $14: 00$ & 25 & 30.1 & 30.7 & 31.4 & 29.4 & 26.4 \\
\cline { 2 - 8 } & $15: 00$ & 27 & 32.3 & 32.4 & 33.8 & 34.8 & 27.0 \\
\cline { 2 - 8 } & $16: 00$ & 28 & 35.7 & 35.0 & 35.1 & 36.1 & 27.1 \\
\cline { 2 - 8 } & $17: 00$ & 25 & 32.1 & 32 & 32.1 & 31.1 & 25.1 \\
\cline { 2 - 8 } & $18: 00$ & 23 & 30.0 & 29.9 & 30.5 & 25.7 & 24.8 \\
\hline \multirow{5}{*}{14.01 .2021} & $7: 00$ & -19.4 & -19.2 & -19.1 & -19.4 & -19.4 & -17.3 \\
\cline { 2 - 8 } & $10: 00$ & -17.1 & -18.0 & -18.4 & -18.0 & -18.1 & -16.4 \\
\cline { 2 - 8 } & $12: 00$ & -11.3 & -12.2 & -12.1 & -11.4 & -14.1 & -14.7 \\
\cline { 2 - 8 } & $14: 00$ & -8.8 & -8.1 & -8.1 & -8.2 & -12.1 & -12.1 \\
\cline { 2 - 8 } & $16: 00$ & -10.8 & -6.8 & -6.8 & -6.4 & -13.1 & -13.4 \\
\hline
\end{tabular}

Table 1 shows that the temperature is distributed unevenly along the vertical direction of the reinforced concrete beam. Within the metal beam, the temperature is distributed more evenly, with a difference of up to $1.0^{\circ} \mathrm{C}$.

Of the greatest interest is the distribution of temperature in the area where a metal beam meets a reinforced concrete slab, these are points 4 and 5 . At these points, there is a temperature difference between a metal beam and a reinforced concrete slab. The maximum registered temperature difference was $+9{ }^{\circ} \mathrm{C}$ at positive ambient temperatures, and $-2.1^{\circ} \mathrm{C}$ at negative ambient temperatures.

nIt should be noted that a significant difference in temperature drop at the junction of a metal beam and a reinforced concrete slab is caused by the different physical and mechanical properties of structural materials. The temperature difference between the metal beam and the reinforced concrete slab could lead to temperature stresses and deformations in beams. Therefore, to determine the stressed-strained state of the reinforced concrete beams of the bridge under the influence of variable climatic temperature changes in the environment, it is necessary to build mathematical models for assessing the temperature field and the thermally stressed state.

5. 2. A one-dimensional mathematical model for assessing a temperature field and the stressed state of the reinforced concrete beam of the bridge

To assess the distribution of temperature across a bridge's reinforced concrete beam, we improved the model reported in work [18]. The lower part of the model represents a metal beam (upper shelf), and the upper part of the model is a reinforced concrete slab (Fig. 3). Only the estimation area of the model is considered; it is highlighted by a dashed line.



Fig. 3. Model for calculating temperature field and stresses

To assess the temperature stresses in the reinforced concrete beam of the bridge, a problem on temperature was solved at the first stage. To this end, we derived the distribution of a temperature field in the vertical direction of the beam from the following equation:

$$
t=\left\{\begin{array}{l}
C_{1} z+C_{2}, 0 \leq z \leq z_{1}, \\
C_{3} z+C_{4}, z_{1}<z \leq h,
\end{array}\right.
$$

where the integration constants, included in equation (1), take the form:

$$
\begin{aligned}
& C_{1}=\frac{t_{2}-t_{1}}{z_{1}+\frac{k_{1}}{k_{2}}\left(h-z_{1}\right)} ; C_{2}=t_{1} ; \\
& C_{3}=\frac{k_{1}}{k_{2}} C_{1} ; C_{4}=t_{2}-C_{3} h .
\end{aligned}
$$

To assess the distribution of the temperature field, the following initial parameters of the model are assigned: the thickness of the upper shelf and the reinforced concrete slab is $h=314 \mathrm{~mm}$, out of which $z_{1}=14 \mathrm{~mm}$ is the thickness of the metal upper shelf of the beam. Thermal conductivity coefficients of the corresponding structural materials are $k_{1}=45 \mathrm{~W} /\left(\mathrm{m} \cdot{ }^{\circ} \mathrm{C}\right)$; $k_{2}=19 \mathrm{~W} /\left(\mathrm{m} \cdot{ }^{\circ} \mathrm{C}\right)$. The adopted maximum and minimum temperature values of the metal beam $t_{1}$ and the reinforced concrete slab $t_{2}$ are those registered during the process of experimental measurements.

Fig. 4 shows the distribution of the temperature field in the reinforced concrete beam of the bridge under the action of the maximum positive and minimum negative ambient temperatures derived from solving equation (1).

Fig. 4 shows that at the same ambient temperature values, the temperature at the surfaces of the metal beam $\left(T_{4}\right)$ is higher than the temperature of the reinforced concrete slab $\left(T_{5}\right)$.

A temperature jump is observed at the boundary of connection of the metal beam and reinforced concrete slab. Therefore, to assess the magnitude of temperature stresses in the reinforced concrete beam of the bridge, a known formula given in work [18] was applied:

$$
\sigma_{1}=-\frac{\alpha t E}{1-v}, \sigma_{2}=-\frac{\alpha t E}{1-v} .
$$

We determined temperature stresses in the reinforced concrete beam of the bridge at the physical and mechanical parameters of the metal beam and reinforced concrete slab given in Table 2. 


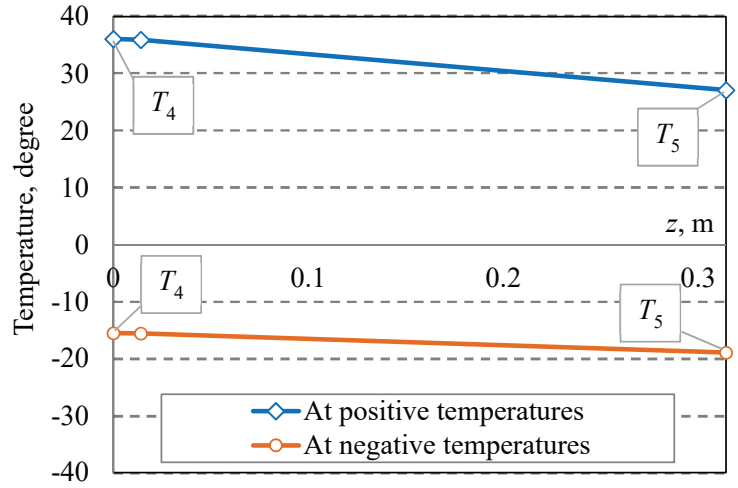

Fig. 4. Temperature field distribution by thickness in the bridge's reinforced concrete beam

Table 2

Physical and mechanical characteristics of a reinforced concrete beam

\begin{tabular}{|c|c|c|c|}
\hline $\begin{array}{c}\text { No. of } \\
\text { entry }\end{array}$ & Characteristic name & Value & $\begin{array}{c}\text { Dimen- } \\
\text { sionality }\end{array}$ \\
\hline 1 & $\begin{array}{c}\text { Modulus of elasticity of a metal } \\
\text { beam, } E_{1}\end{array}$ & $2.1 \cdot 10^{5}$ & $\mathrm{MPa}$ \\
\hline 2 & $\begin{array}{c}\text { Modulus of elasticity of reinforced } \\
\text { concrete slab, } E_{2}\end{array}$ & $3.6 \cdot 10^{4}$ & $\mathrm{MPa}$ \\
\hline 3 & Poisson's ratio of a metal beam $v_{1}$ & 0.3 & \\
\hline 4 & $\begin{array}{c}\text { Poisson's ratio of reinforced con- } \\
\text { crete slab } v_{2}\end{array}$ & 0.25 & \\
\hline 5 & $\begin{array}{c}\text { Coefficients of linear thermal } \\
\text { expansion of a metal beam, } \alpha_{1}\end{array}$ & $1.25 \cdot 10^{-5}$ & $1 /{ }^{\circ} \mathrm{C}$ \\
\hline 6 & $\begin{array}{c}\text { Coefficients of linear thermal expan- } \\
\text { sion of reinforced concrete slab, } \alpha_{2}\end{array}$ & $1.0 \cdot 10^{-5}$ & $1 /{ }^{\circ} \mathrm{C}$ \\
\hline 7 & $\begin{array}{c}\text { The thermal conductivity of the } \\
\text { metal beam, } k_{1}\end{array}$ & 45 & $\mathrm{~W} /\left(\mathrm{m} \cdot{ }^{\circ} \mathrm{C}\right)$ \\
\hline 8 & $\begin{array}{c}\text { Coefficient of thermal conductivity } \\
\text { of reinforced concrete slab, } k_{2}\end{array}$ & 19 & $\mathrm{~W} /\left(\mathrm{m} \cdot{ }^{\circ} \mathrm{C}\right)$ \\
\hline
\end{tabular}

The results of our calculations of stresses in the reinforced concrete beam (Fig. 5) demonstrate that the metal beam is exposed to higher stresses than those in the reinforced concrete slab ( $T_{4}, T_{5}$, respectively, Fig. 2). A sharp change in stresses occurs at the border between the metal and reinforced concrete parts of the beam. At the temperatures of the surface of the metal part of the beam of $+36.1{ }^{\circ} \mathrm{C}$, and of the reinforced concrete slab of $+27.1{ }^{\circ} \mathrm{C}$, the stresses amount to $89,8 \mathrm{MPa}$; at the temperatures of the metal beam of $-19.4{ }^{\circ} \mathrm{C}$, and the reinforced concrete slab of $-17.1^{\circ} \mathrm{C}$, the maximum stresses equal $58.37 \mathrm{MPa}$.

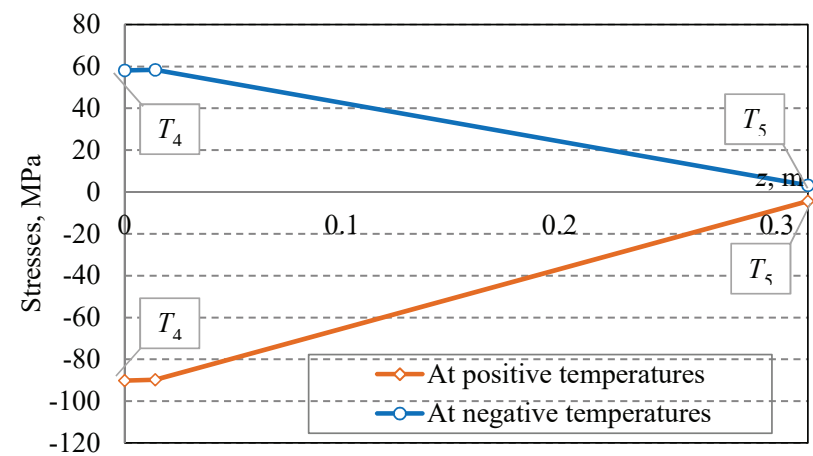

Fig. 5. The distribution of stresses in the bridge's reinforced concrete beam
The result of our study into the impact of the environmental temperature drop on the stressed-strained state of the reinforced concrete beams of bridges has established that the level of stresses is more than $35 \%$ of the permissible values of stresses equal to $235 \mathrm{MPa}$.

The level of temperature stresses is significant, so temperature stresses must be taken into consideration when designing reinforced concrete beams for bridges.

5. 3. Estimating the temperature stresses and deformations in reinforced concrete beams by a finite-element method

Since reinforced concrete bridges have a complex geometric configuration, which cannot be accounted for in one-dimensional or two-dimensional problems, we estimated the stressed-strained state of the beam by a finite-element method for the three-dimensional statement of the research task [21].

To determine temperature stresses and deformations, the length of the reinforced concrete beam is taken to equal $2,000 \mathrm{~mm}$. The profile number of the I-beam is $100 \mathrm{~B}$ (GOST 6183-52). The reinforced concrete slab has the following dimensions: width, $b=1,000 \mathrm{~mm}$; the height at the ends of the slab, $h_{1}=160 \mathrm{~mm}$; the height above the top shelf of the metal beam, $h_{2}=400 \mathrm{~mm}$. The physical and mechanical characteristics of the metal beam and reinforced concrete slab are given in Table 1.

The boundary conditions are accepted in the form of a fixed fastening on the left side of the beam, and a movable fastening on the right side of the beam.

The studied fragment of the reinforced concrete beam is split into a grid of three-dimensional finite elements of tetrahedra type [22]. The number of nodes in the finite-element grid is 36,125 pieces, which form 22,416 elements.

For a comprehensive assessment of the stressed-strained state of the reinforced concrete beam of the bridge exerted by the effect of ambient temperature, we determine at the first stage the distribution of the temperature field, and, at the second stage, we determine the temperature stresses and deformation of the beam.

The results of the temperature field distribution (Fig. 6) over the surfaces of the reinforced concrete beam demonstrate that it is distributed unevenly. The maximum temperature is shown by the metal beam; at the border of connecting the metal beam with the reinforced concrete slab, the temperature decreases, and the lowest temperature value is observed in the reinforced concrete slab. In the vertical direction of the beam, the temperature ranges from $+27{ }^{\circ} \mathrm{C}$ to $+35^{\circ} \mathrm{C}$ at positive ambient temperatures (Fig. 6, $a$ ), and from $-19.6^{\circ} \mathrm{C}$ to $-15.7^{\circ} \mathrm{C}$ at negative ambient temperatures (Fig. 6, b).

When analyzing the distribution of the temperature field in the transverse direction of the beam, it was established that the temperature in the metal beam is distributed evenly. However, in the reinforced concrete slab, the temperature difference between the outer and inner surfaces of the slab was $+8.1{ }^{\circ} \mathrm{C}$ at positive temperatures and $-3.9{ }^{\circ} \mathrm{C}$ at negative temperatures.

The results of calculating the thermally strained state of the reinforced concrete beam of the bridge under the influence of positive and negative ambient temperatures are shown in Fig. 7. The results that were derived from calculating the stresses by Mises (Fig. 7, $a$ ) established that the maximum stresses arise at the place where a metal beam meets a reinforced concrete slab. The value of these stresses is $73.4 \mathrm{MPa}$, which is up to $35 \%$ of the permissible values of stresses for a beam's metal. At negative temperatures, the stresses were 69.3 $\mathrm{MPa}$. 


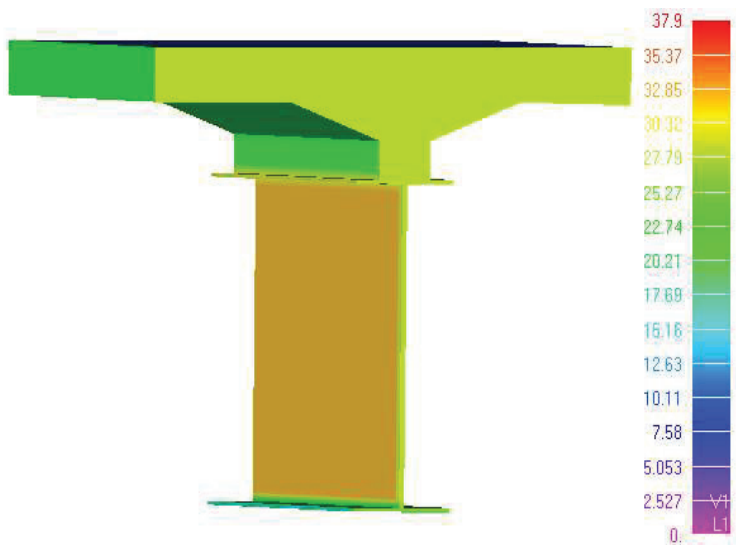

$a$

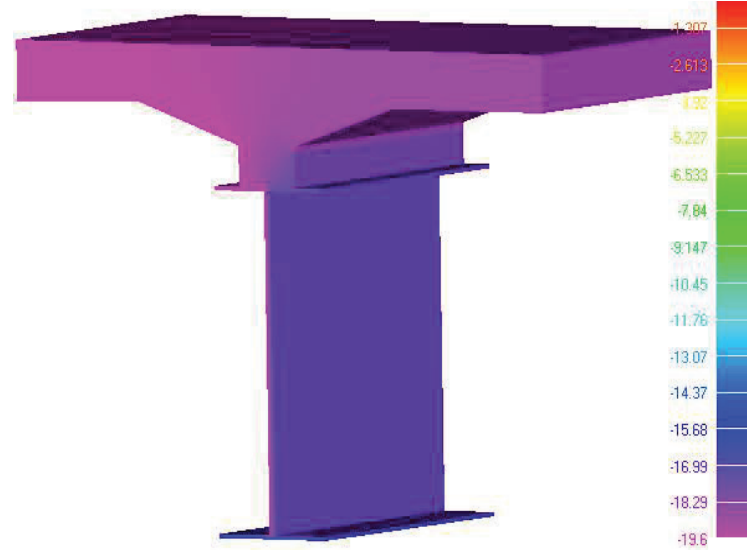

$b$

Fig. 6. Temperature field distribution in a reinforced concrete beam: $a-$ at positive ambient temperatures, $b-$ at negative ambient temperatures

The resulting level of temperature stresses of the reinforced concrete beam of the bridge is high. A combination of stresses caused by the action of vehicles and the effect of variable climatic temperature influences could lead to exceeding the permissible stresses in bridges' reinforced concrete beams. This emphasizes the need to take into con-



$a$

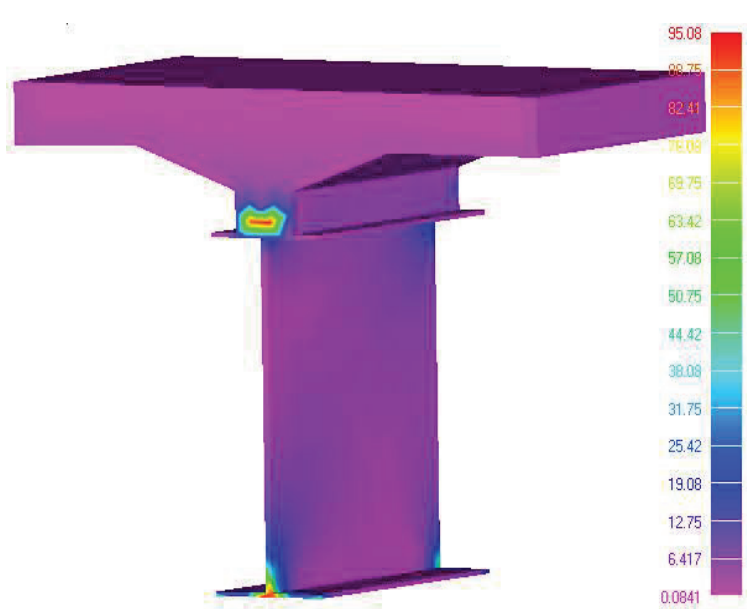

b

Fig. 7. Thermally strained state of a reinforced concrete beam: $a-$ at positive ambient temperatures, $b-$ at negative ambient temperatures sideration the effect of climatic temperature influences on the stressed-strained state of reinforced concrete bridges.

The maximum values of deformations of the reinforced concrete beam of the bridge are $0.0171 \mathrm{~mm}$ (Fig. 8, $a$ ) at positive temperatures and $0.00354 \mathrm{~mm}$ (Fig. $8, b)$ at negative temperatures.

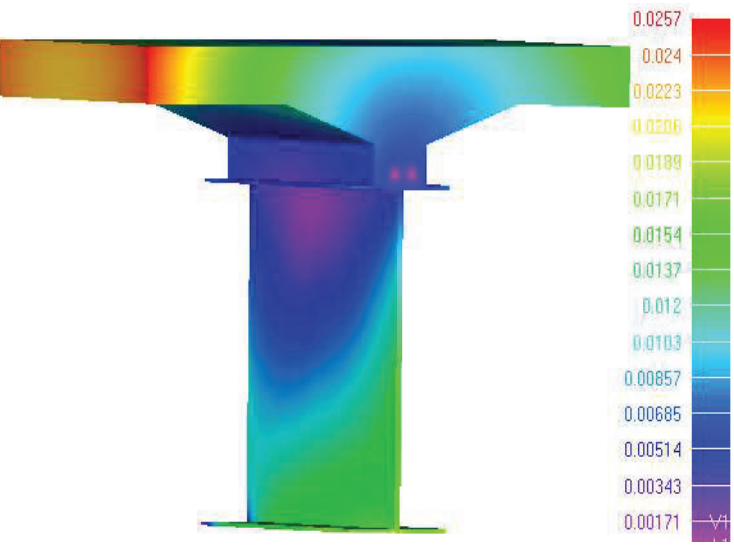

$a$



$b$

Fig. 8. Temperature deformations of a bridge's reinforced concrete beam: $a-$ at positive ambient temperatures, $b-$ at negative ambient temperatures 
It should be noted that in the place of contact between the metal beam and the reinforced concrete slab the amount of deformations is small. Therefore, in this contact, there are maximum stresses during the action of climatic temperature changes in the environment.

The maximum value of tangent stresses in the contact between a metal beam and a reinforced concrete slab was 27.58 $\mathrm{MPa}$ at positive ambient temperatures.

\section{Discussion of results of estimating the thermally strained state of a bridge's reinforced concrete beam}

Our experimental measurements of temperature distribution at the surfaces of reinforced concrete beams of bridges have established that the temperature spreads unevenly along the vertical direction of a reinforced concrete beam. Namely, in the contact between the metal beam and reinforced concrete slab, there is a sharp temperature drop (Table 1). The maximum registered temperature difference between the metal beam and reinforced concrete slab at positive ambient temperatures was $+9.0{ }^{\circ} \mathrm{C}\left(T_{4}, T_{5}\right.$, respectively, Table 1); the minimum temperature difference between the beams, at the same points, at negative ambient temperature values was $-2.1{ }^{\circ} \mathrm{C}$.

As a result of different modulus of elasticity and the coefficients of temperature expansion of steel and concrete in a bridge's reinforced concrete beams, the area of the rigid connection between a metal beam and a reinforced concrete slab is exposed to maximum stresses. The value of these stresses is $73.4 \mathrm{MPa}$ (Fig. 7, $a$ ) at positive temperatures, and 69.3 MPa at negative temperatures (Fig. 7, b). A similar level of stresses was reported in work [20] when studying the thermally stressed state of a reinforced concrete pipe strengthened with a metal corrugated structure.

The value of temperature stresses is more than $35 \%$ of permissible stresses equal to $235 \mathrm{MPa}$. When combined with the effect of stresses from moving vehicles, they cause cracks and various damage to the structural materials of the reinforced concrete beam. Therefore, the overall stressedstrained state of the reinforced concrete beams of a bridge should be assessed at the joint action of temperature climatic influences and loads from moving vehicles.

The occurrence of local defects in the area of connecting metal beams with a reinforced concrete slab is explained by the different values of structural materials' elasticity modules and a significant temperature difference. The temperature difference between the metal beam and the reinforced concrete slab leads to the emergence of temperature stresses. This issue is especially relevant for reinforced concrete bridges, in which a metal beam is rigidly connected to a reinforced concrete slab. Therefore, to ensure the durable operation of reinforced concrete bridges, it is necessary to design effective structural solutions for combining a metal beam with a reinforced concrete slab.

One limitation of this study is the lack of experimental data on the distribution of temperature along the length of the reinforced concrete beam and determining its effect on the thermally strained state of the bridge beam. Therefore, we plan to continue research by taking into consideration the distribution of temperature along the length of the reinforced concrete beam at maximum and minimum ambient temperatures.

In addition, it should be noted that the derived thermally strained state could be taken into consideration when designing a bridge's reinforced concrete beams for the maximum ambient temperature of $+28^{\circ} \mathrm{C}$ and the minimum temperature of $-19.4^{\circ} \mathrm{C}$. At higher climatic temperatures, it is necessary to carry out an additional assessment of the thermally stressed state of the steel-reinforced concrete bridge using formula (1) to determine a temperature field, and formula (3) - temperature stresses.

\section{Conclusions}

1. The results from our experimental temperature measurements at the surfaces of reinforced concrete beams of bridges have established that the temperature is distributed unevenly in the vertical direction. Within the metal beam, the temperature spreads more evenly, with a difference of up to $1.0^{\circ} \mathrm{C}$. In the contact area of a metal beam with a reinforced concrete slab, the maximum registered temperature difference was $+9.0^{\circ} \mathrm{C}$.

2. To assess the thermally stated state of the reinforced concrete beams of the bridge, we have improved the mathematical models for calculating a temperature field and the thermally strained state under the influence of different climatic temperatures in the environment, by taking into consideration the uneven distribution of temperature in the vertical direction of the beam and various physical and mechanical parameters of structural materials. That makes it possible to assess the thermally strained state of reinforced concrete beams, which have a complex geometric shape and include various structural materials (a metal beam and a reinforced concrete slab). It was established that a one-dimensional problem could be considered, or three-dimensional problem estimation schemes could be used, as the estimation schemes for determining the thermally strained state of reinforced concrete beams.

3 . The stresses that are caused by climatic temperature changes in the reinforced concrete beams of bridges make up more than $35 \%$ of the permissible values of stresses equal to $235 \mathrm{MPa}$. That necessitates taking them into consideration when designing reinforced concrete beams for bridges at the joint action of transport means.

\section{References}

1. Balabuh, Ya. (2010). Efficiency of steel-reinforced road bridges. Dorogi $i$ mosti, 12, 16-23. Available at: http://dorogimosti.org.ua/ ua/efektivnisty-stalezalizobetonnih-avtodoroghnih-mostiv

2. Kovalchuk, V. V. (2012). Stan ta problemy zabezpechennia dovhovichnosti prohonovykh budov mostiv. Zbirnyk naukovykh prats DonIZT, 32, 226-235.

3. Koval, P. M., Balabukh, Ya. A. (2012). Problemy zabezpechennia dovhovichnosti stalebetonnykh mostiv. Mekhanika i fizyka ruinuvannia budivelnykh materialiv ta konstruktsiy, 9, 426-443. 
4. Kovalchuk, V., Markul, R., Bal, O., Milyanych, A., Pentsak, A., Parneta, B., Gajda, A. (2017). The study of strength of corrugated metal structures of railroad tracks. Eastern-European Journal of Enterprise Technologies, 2 (7 (86)), 18-25. doi: https://doi.org/ 10.15587/1729-4061.2017.96549

5. Kovalchuk, V. (2014). Study of temperature field and stress state of metal convoluted pipes. Resursoekonomni materialy, konstruktsii, budivli ta sporudy, 29, 186-192. Available at: http://nbuv.gov.ua/UJRN/rmkbs_2014_29_29

6. Beben, D. (2017). Experimental Testing of Soil-Steel Railway Bridge Under Normal Train Loads. Experimental Vibration Analysis for Civil Structures, 805-815. doi: https://doi.org/10.1007/978-3-319-67443-8_71

7. Li, D., Maes, M. A., Dilger, W. H. (2004). Thermal design criteria for deep prestressed concrete girders based on data from Confederation Bridge. Canadian Journal of Civil Engineering, 31 (5), 813-825. doi: https://doi.org/10.1139/104-041

8. Pisani, M. A. (2004). Non-linear strain distributions due to temperature effects in compact cross-sections. Engineering Structures, 26 (10), 1349-1363. doi: https://doi.org/10.1016/j.engstruct.2004.04.004

9. Barr, P. J., Stanton, J. F., Eberhard, M. O. (2005). Effects of Temperature Variations on Precast, Prestressed Concrete Bridge Girders. Journal of Bridge Engineering, 10 (2), 186-194. doi: https://doi.org/10.1061/(asce)1084-0702(2005)10:2(186)

10. AASHTO LRFD bridge design specifications (2008). Washington, DC: American Association of State Highway and Transportation Officials. Available at: https://www.worldcat.org/title/aashto-lrfd-bridge-design-specifications/oclc/317485511

11. Lee, J.-H. (2010). Experimental and analytical investigations of the thermal behavior of prestressed concrete bridge girders including imperfections. Georgia Institute of Technology Atlanta, GA, 302. Available at: https://smartech.gatech.edu/handle/1853/34675

12. DBN V.1.2-15:2009. Sporudy transportu. Mosty ta truby. Navantazhennia i vplyvy. K.: Minbud Ukrainy, 84. Available at: http:// kbu.org.ua/assets/app/documents/dbn2/48.1.\%20\%D0\%94\%D0\%91\%D0\%9D\%20\%D0\%92.1.2-15 2009.\%20\%D0\%A1\%D0\% BF\%D0\%BE\%D1\%80\%D1\%83\%D0\%B4\%D0\%B8\%20\%D1\%82\%D1\%80\%D0\%B0\%D0\%BD\%D1\%81\%D0\%BF\%D0\%BE\%D1\%80\%D1\%82\%D1\%83.\%20\%D0\%9C\%D0\%BE\%D1\%81\%D1\%82\%D0\%B8\%20\%D1\%82\%D0\%B0\%20\%D1\%82\%D1\%80.pdf

13. Luchko, Y. Y., Sulym, H. T., Kyrian, V. I. (2004). Mekhanika ruinuvannia mostovykh konstruktsii ta metody prohnozuvannia yikh zalyshkovoi dovhovichnosti. Lviv: Kameniar, 885. Available at: http://94.158.152.98/opac/index.php?url=/notices/index/ IdNotice:85921/Source:default.

14. De Backer, H., Outtier, A., Van Bogaert, P. (2009). Numerical and experimental assessment of thermal stresses in steel box girders. Conference: Nordic Steel Construction Conference, 11th, Proceedings, 65-72. Available at: https://www.researchgate.net/ publication/259004379_Numerical_and_experimental_assessment_of_thermal_stresses_in_steel_box_girders

15. Balmes, E., Corus, M., Siegert, D. (2006). Modeling thermal effects on bridge dynamic responses. Available at: https://www.researchgate.net/publication/228758158

16. Zahabizadeh, B., Edalat-Behbahani, A., Granja, J., Gomes, J. G., Faria, R., Azenha, M. (2019). A new test setup for measuring early age coefficient of thermal expansion of concrete. Cement and Concrete Composites, 98, 14-28. doi: https://doi.org/10.1016/ j.cemconcomp.2019.01.014

17. Dilger, W. H., Ghali, A., Chan, M., Cheung, M. S., Maes, M. A. (1983). Temperature Stresses in Composite Box Girder Bridges. Journal of Structural Engineering, 109 (6), 1460-1478. doi: https://doi.org/10.1061/(asce)0733-9445(1983)109:6(1460)

18. Luchko, J., Hnativ, Yu., Kovalchuk, V. (2013). Temperature field and stressed state of composite bridge span investigation. Visnyk Ternopilskoho natsionalnoho tekhnichnoho universytetu, 2, 29-38. Available at: http://eadnurt.diit.edu.ua/jspui/ handle/123456789/9759.

19. Gera, B., Kovalchuk, V. (2019). A study of the effects of climatic temperature changes on the corrugated structure. EasternEuropean Journal of Enterprise Technologies, 3 (7 (99)), 26-35. doi: https://doi.org/10.15587/1729-4061.2019.168260

20. Kovalchuk, V., Hnativ, Y., Luchko, J., Sysyn, M. (2020). Study of the temperature field and the thermo-elastic state of the multilayer soil-steel structure. Roads and Bridges - Drogi i Mosty, 19 (1), 65-78. doi: https://doi.org/10.7409/rabdim.020.004

21. Luchko, Y. Y., Kovalchuk, V. V. (2012). Vymiriuvannia napruzheno-deformovanoho stanu konstruktsiy mostiv pry zminnykh temperaturakh i navantazhenniakh. Lviv: Kameniar, 235.

22. Rudakov, K. M. (2009). Vstup u UGS Femap 9.3 (for Windows NT). Heometrychne ta skinchenno-elementne modeliuvannia konstruktsiy. Kyiv: NTUU «KPI», 282. Available at: http://mmi-dmm.kpi.ua/images/pdf/personnel/RUDAKOV/publicacii/ Femap93_PDF/Femap93.htm 